ICAMS 2016 $-6^{\text {th }}$ International Conference on Advanced Materials and Systems

\title{
MEDICAL BIOPRODUCTS COLLAGEN QUANTIFICATION BY
} HYDROXYPROLINE DETERMINATION

\author{
GABRIELA MACOVESCU, CIPRIAN CHELARU, MĂDĂLINA GEORGIANA ALBU \\ KAYA, LUMINI A ALBU \\ INCDTP - Division Leather and Footwear Research Institute, 93 Ion Minulescu St., icpi@icpi.ro
}

\begin{abstract}
The paper presents a method of quantifying collagen from medical collagen-based bioproducts obtained in the Collagen Research Department of INCDTP - Division ICPI by determining hydroxyproline. Collagen differs from usual proteins in that it contains a higher concentration of certain amino acids. Almost a third of collagen is made up of glycine, the smallest amino acid, and another third is made up of proline and hydroxyproline, the active form of proline. As hydroxyproline has been found in very few proteins other than collagen, hydroxyproline determination is used as a marker to quantify collagen levels from various medical products. Collagen is quantified by multiplying hydroxyproline content by the 6.6 factor. The proposed method was validated to establish performance parameters and to check accordance with the set goal, by determining: limit of detection, limit of quantification, selectivity, sensitivity, robustness, accuracy and reliability of the method.
\end{abstract}

Keywords: collagen, hydroxyproline, medical bioproducts

\section{INTRODUCTION}

Collagen analysis helps to characterize and ensure the safety of a multitude of healthcare products that incorporate this extracellular protein matrix. These applications include wound care, burn care, orthopedic graft products, tissue engineering, hemostatic sponges, injectables for soft tissue augmentation, as a vehicle for drug delivery and as an ingredient in skin and hair care products. Collagen is a highly versatile material and there is a growing interest in the processing and characterization of many types of collagen as developers find new applications. Due to its excellent biocompatibility and biodegradability, well-defined structure, biological characteristics and method of interaction with the body, collagen is one of the most frequently used biomaterials for medical treatment. Extracted in the form of aqueous solution or gel, type I fibrillary collagen may be modelled into various products: medical devices, artificial implants, drug release systems, creams and scaffolds for tissue regeneration, with important role in medicine (Albu et al., 2011; Albu and Titorencu, 2011; Albu et al., 2012a; Vranceanu et al., 2012; Albu et al., 2012b; Albu et al., 2015).

Collagen itself is considered an active drug/principle, used - in various forms - as hemostatic and dressing in the treatment of various types of wounds. Collagen is the basis of intercellular matter of conjunctive tissue found in bones, teeth, cartilage, tendons, ligaments, skin, blood vessels and has an important role in a series of physiological processes, provides resistance and structural integrity to the body. An increase in catabolism and collagen regeneration are important information in the pathogenesis of many diseases.

Collagen, a natural protein, cannot heal infected tissue by itself, as bacteria may use it as a substrate. In severe wound infections, systemic drug administration may lead to insufficient drug concentration at the infected site or to side effects associated to the drug and/or systemic toxicity. This deficiency found its successful resolution in local drug applications, by developing drug release systems using collagen as substrate and an antibiotic/antiseptic as drug for infection control (Albu and Titorencu, 2011; Vranceanu et al., 2012; Albu et al., 2007; Albu et al., 2010). 
The presence of collagen in the body is essential for healing minor skin injuries, as well as wounds in different tissues, for repairing cartilage, ligaments and bones, including even dental degeneration. A natural polymer, collagen is made up of 20 amino acids, arranged in characteristic sequences that form a highly complex conformational structure, organized into four levels, called primary, secondary, tertiary and quaternary structures.

Collagen differs from regular proteins by the fact the it includes a higher concentration of certain amino acids. Almost a third of collagen composition is glycine, the smallest amino acid, and another third is proline and hydroxyproline, the active form of proline, an amino acid specific to collagen. Hydroxyproline is an amino acid that is synthesized from the irreversible post-translational hydroxylation of proline by prolyl hydroxylase. Hydroxyproline is found almost exclusively in the protein collagen, in the Y position of the repeating tripeptide Gly-X-Y. By allowing sharp twisting of the collagen helix, hydroxyproline helps to stabilize the structure of collagen. Since hydroxyproline has been found on so few proteins other than collagen, measurement of hydroxyproline has been used as a marker to quantify levels of collagen and/or gelatin (partial hydrolysis of collagen resulting in a mixture of protein and peptides). In addition, hydroxyproline measurement has been used to identify certain diseases that involve breakdown of collagen.

Quantification of collagen proteins in biomedical products is performed using a determination hydroxyproline method, in which the amount of hydroxyproline is measured and converted to the amount of collagen. However, the conversion factor can be inaccurate because of variation in the content of hydroxyproline. However, in converting hydroxyproline content to collagen type II content, there is little consensus on the appropriate factor. The hydroxyproline conversion factor (CF) for cartilage collagen content is highly variable according to different laboratories: $\mathrm{CF}=6.94 ; 7.1 ; 7.6 ; 8.3$; or 10. Experimentally $\mathrm{CF}=6.6$ for bovine collagen type I (De Ceuninck et al., 2004).

The total collagen content can then be extrapolated by multiplying amount of total hydroxyproline content in each sample by a factor of 6.6, based on the fact that hydroxyproline represents $14.4 \%$ of the amino acid composition of collagen in most mammalian tissues. (De Ceuninck et al., 2004).

Several experimental hydroxyproline determination approaches were found in the literature differing depending the nature of the material to be tested (Macovescu et al., 2016).

Samples subjected to analyses are first hydrolysed with acid to release hydroxyproline. This is generally performed using hydrochloric acid solution $6 \mathrm{M}$ or sulphuric acid $6 \mathrm{M}$ at temperatures from 110 to $130^{\circ} \mathrm{C}$ for 10 to 24 hours, either in sealed tubes or in reflux condensers. Free hydroxyproline is most conveniently quantified colorimetrically after oxidation to pyrrole, which is then reacted specifically with p-dimethylaminobenzaldehyde (Ehrlich's reagent) to produce an intense red-brown compound. Chloramine-T is now generally preferred as oxidant in pyrrole formation.

\section{MATERIALS AND METHOD}

\section{Method Principle}

Hydroxyproline determination is performed taking into account the following three basic steps:

a) hydroxyproline is derivatized from collagen by hydrolysis with sulphuric acid, at high temperature, $105^{\circ} \mathrm{C}$; 
ICAMS $2016-6^{\text {th }}$ International Conference on Advanced Materials and Systems

b) hydroxyproline is oxidized by adding Chloramine-T, and the oxidation product is subjected to decarboxylation to pyrrole, in an acid medium at high temperature;

c) pyrrole combines, in an acid medium, with p-dimethylaminobenzaldehyde $(\mathrm{DMAB})$ and the resulting addition product is determined by measuring the solution absorbance at $558 \mathrm{~nm}$.

Hydroxyproline content is calculated and expressed as mass percentage.

\section{Reagents}

Only known analytical grade reagents (SIGMA ALDRICH) and distilled water, demineralized water or water equivalent in purity are used.

1. Sulphuric acid solution, $3 \mathrm{~mol} / \mathrm{L}$.

2. Buffer solution, $\mathrm{pH}=6.8$, consisting of:

- $\quad 26.0 \mathrm{~g}$ citric acid monohydrate;

- $\quad 14.0$ g sodium hydroxide;

- $\quad 78.0 \mathrm{~g}$ sodium acetate anhydrous

Reagents are dissolved in $500 \mathrm{~mL}$ water and quantitatively transferred in a 1 litre volumetric flask. $250 \mathrm{~mL} \mathrm{~N}$-propanol are added and water is filled up to the mark. When stored at the temperature of $4^{\circ} \mathrm{C}$ in the dark, this solution is stable up to a few weeks.

\section{Chloramine-T}

$1.41 \mathrm{~g} \mathrm{~N}$-chloro-p-toluenesulfonamide sodium salt trihydrate (Chloramine-T) are dissolved in $100 \mathrm{~mL}$ buffer solution. This solution is prepared immediately before use.

4. Colour reagent

$10.0 \mathrm{~g}$ p-dimethylaminobenzaldehyde are dissolved in $35 \mathrm{~mL}$ perchloric acid solution $[60 \%(\mathrm{~m} / \mathrm{m})]$ and then $65 \mathrm{~mL}$ isopropanol are slowly added. This solution is prepared on the day it is used.

5. Hydroxyproline, standard solutions

A stock solution is prepared by dissolving $50 \mathrm{mg}$ hydroxyproline in water in a 100 $\mathrm{mL}$ volumetric flask. 1 drop sulphuric acid solution is added and filled up to the mark with water. This solution is stable for at least 1 month, stored at $4{ }^{\circ} \mathrm{C}$.

On the day of use, $5 \mathrm{~mL}$ stock solution is transferred into a $500 \mathrm{~mL}$ volumetric flask and filled up to the mark with water. Four standard solutions are then prepared by diluting $10 \mathrm{~mL}$, $20 \mathrm{~mL}, 30 \mathrm{~mL}$ and $40 \mathrm{~mL}$ of this solution with water up to $100 \mathrm{ml}$ to obtain hydroxyproline concentrations of $0.5 \mu \mathrm{g} / \mathrm{mL}, 1 \mu \mathrm{g} / \mathrm{mL}, 1.5 \mu \mathrm{g} / \mathrm{mL}$, and $2 \mu \mathrm{g} / \mathrm{mL}$, respectively.

\section{Equipment}

- Spectrometer, suitable for use at a wavelength of $558 \mathrm{~nm} \pm 2 \mathrm{~nm}$, or a photoelectric colorimeter with an interference filter with maximum absorption at $558 \mathrm{~nm} \pm 2 \mathrm{~nm}$. Glass cells with optical path length of $10 \mathrm{~mm}$ are used.

- Adjustable oven at $105^{\circ} \mathrm{C} \pm 2^{\circ} \mathrm{C}$;

- Analytical scales with accuracy of $0.0001 \mathrm{~g}$;

- Adjustable water bath at $60^{\circ} \mathrm{C}$.

\section{Work Method}

\section{Sample Preparation}

a. Approximately $0.5-1 \mathrm{~g}$ sample are weighed with an accuracy of $0.0001 \mathrm{~g}$ in hydrolysis tubes so that the sample does not adhere to the walls. 
b. $10 \mathrm{~mL}$ sulphuric acid solution (1) are added, the tube is covered and placed in the oven at $105^{\circ} \mathrm{C} \pm 2^{\circ} \mathrm{C}$ for 16 hours for hydrolysis.

c. The resulting hydrolysate is transferred into a $250 \mathrm{~mL}$ volumetric flask and filled with water up to the mark.

d. Using a pipette, a volume $\mathrm{V}$ is added into a $250 \mathrm{~mL}$ volumetric flask and filled with water up to the mark. Volume $\mathrm{V}$ will be taken so that hydroxyproline content would range between $0.5 \mu \mathrm{g} / \mathrm{mL}$ and $2 \mu \mathrm{g} / \mathrm{mL}$.

e. $4.00 \mathrm{~mL}$ of this solution (d) is transferred into a test tube and $2.00 \mathrm{~mL}$ Chloramine-T reagent is added (3). The solution is stirred and left at room temperature for $20 \mathrm{~min} \pm 1 \mathrm{~min}$.

f. $2.00 \mathrm{~mL}$ colour reagent (4) is added, mixed thoroughly and the lid of the tube is covered with aluminium or plastic foil (5.6).

g. The tube is rapidly transferred into the water bath (5.7), set at $60^{\circ} \mathrm{C}$ and heated for 20 minutes precisely.

h. The tube is cooled under tap water stream for at least 3 minutes and left at room temperature for $30 \mathrm{~min}$.

i. Absorbance is measured at $558 \mathrm{~nm} \pm 2 \mathrm{~nm}$ in a glass cell compared to a blank of reagents.

j. To convert HYP to collagen, we can multiply the result by factor of 6.6

\section{Calibration Curve}

The procedure described from item e. to i. included is performed on standard hydroxyproline using $4.00 \mathrm{ml}$ of the four diluted solutions. The calibration curve is plotted. Values for analyzed samples are read and concentration is calculated depending on the mass of the sample, dilutions and the sample volume $\mathbf{V}$ taken in item $\mathbf{d}$.

\section{RESULTS AND DISCUSSIONS}

Collagen biomaterials for medical use from the Collagen Department of INCDTP Division ICPI, namely collagen hydrolysates, gels and matrices used in wound treatment (Pancol, Gevicol), were studied to determine hydroxyproline (Albu et al., 2012b; Albu et al., 2015; Albu et al., 2007; Albu et al., 2010). Samples were physically-chemically characterised and the results are presented in Table 1:

Table 1. Characterization of collagen biomaterials for medical use

\begin{tabular}{ccccc}
\hline Characteristics & Dry matter, \% & Ash*, \% & $\begin{array}{c}\text { Total } \\
\text { nitrogen*, } \%\end{array}$ & Appearance \\
Biomaterial & 85.69 & 2.37 & 15.68 & Spongious white foil \\
\hline Pancol batch 4 & 84.40 & 2.93 & 16.29 & Spongious white foil \\
Pancol batch 5 & 87.47 & 2.62 & 16.35 & Spongious violet foil \\
Gevicol batch 4 & 86.72 & 2.46 & 15.90 & Spongious violet foil \\
Gevicol batch 5 & 2.98 & 0.87 & 16.28 & Transparent gel \\
Collagen gel batch 4 & 3.45 & 0.43 & 16.08 & Transparent gel \\
Collagen gel batch 5 & 84.95 & 1.99 & 16.97 & Yellowish powder \\
Hydrolysate COL 24 & 85.55 & 1.76 & 17.15 & Yellowish powder \\
Hydrolysate COL 25 & & & \\
\hline
\end{tabular}

*values are recalculated without volatile matter

Chloramine- $\mathrm{T}$ (N-chloro-4-toluenesulfonamide sodium salt) was used as oxidation agent, as its indisputable advantages include easy decomposition of its excess and absence 
ICAMS $2016-6^{\text {th }}$ International Conference on Advanced Materials and Systems

of coloured reduction products. The oxidation reaction is performed in a buffer solution with $\mathrm{pH} \sim 6.8$. Hydroxyproline oxidation is illustrated by the following reactions:

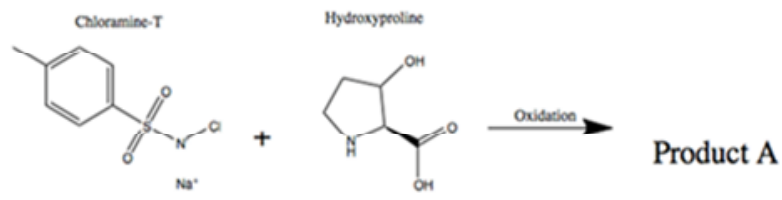

The postulated mechanism for the oxidation of hydroxyproline to pyrrole is as follows (2): first hydroxyproline (I) is oxidized to a linear compound, $\alpha$-keto- $\gamma$-hydroxy- $\delta$ aminovaleric acid (II), which is in equilibrium with the pyrroline-4-hydroxy -2-carboxylic acid with cyclic structure (III). The loss of water gives an unstable structure (IV), which spontaneously rearranges to pyrrole-2-carboxylic acid (V). The final step of decarboxylation to pyrrole (VI) takes place during the heating after the addition of the chromogenic reagent for pyrrole, p-dimethylaminobenzaldehyde (Etherington and Sims, 1981).

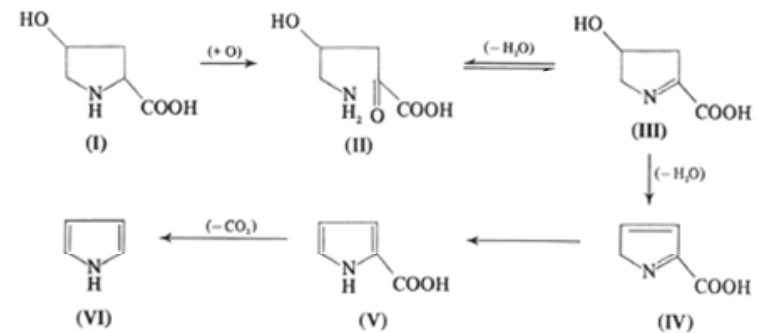

Chromophore formation is illustrated in the following reaction:

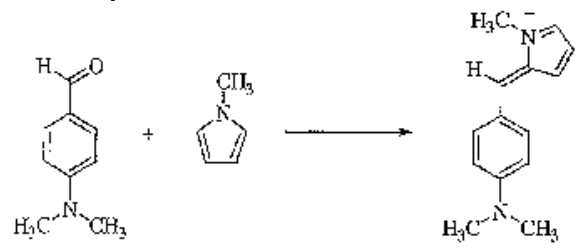

As the products tested have a much higher collagen content, the amount of sample tested was modified. Also, as the product in question is collagen hydrolysate, we considered it necessary to use more diluted mineral acids for hydrolysis, 3 molar.

Values for hydroxyproline and collagen in bioproducts for medical use determined using the adapted method are in accordance with literature data. Each value is the average of 10 replicated determinations, presented in Table 2.

Table 2. Hydroxyproline and collagen content of biomaterials for medical use

\begin{tabular}{ccccccccc}
\hline Biomaterial & $\begin{array}{c}\text { Pancol } \\
\text { batch } \\
4\end{array}$ & $\begin{array}{c}\text { Pancol } \\
\text { batch } \\
5\end{array}$ & $\begin{array}{c}\text { Gevicol } \\
\text { batch 4 }\end{array}$ & $\begin{array}{c}\text { Gevicol } \\
\text { batch 5 }\end{array}$ & $\begin{array}{c}\text { Coll. } \\
\text { gel } \\
\text { batch } \\
4\end{array}$ & $\begin{array}{c}\text { Coll. } \\
\text { gel } \\
\text { batch } \\
5\end{array}$ & $\begin{array}{c}\text { Hydrolysate } \\
\text { COL 24 }\end{array}$ & $\begin{array}{c}\text { Hydrolysate } \\
\text { COL 25 }\end{array}$ \\
\hline $\begin{array}{c}\text { Hydroxyproline, } \% \\
\text { Collagen, \% }\end{array}$ & $14.01^{*}$ & $14.22^{*}$ & $14.53^{*}$ & $14.65^{*}$ & $15.02^{*}$ & $15.12^{*}$ & $13.53^{*}$ & $13.77^{*}$ \\
\hline * values are recalculated without volatile matter & $93.85^{*}$ & $95.89^{*}$ & $96.69^{*}$ & $99.13^{*}$ & $99.66^{*}$ & $89.30^{*}$ & $90.88^{*}$ \\
\hline
\end{tabular}




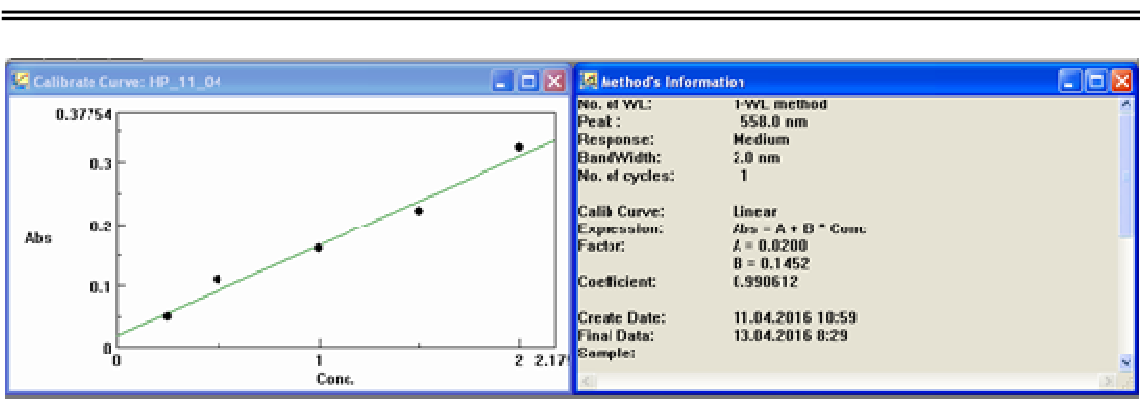

Figure 2. Linearity range for concentrations ranging between $0.5 \mathrm{~g} / \mathrm{mL}$ and $2 \mathrm{~g} / \mathrm{mL}$

Ten replicated samples of $1.5 \mu \mathrm{g} / \mathrm{mL}$ hydroxyproline concentration were prepared and Yi values were measured (integrated units) for signal intensity at $558 \mathrm{~nm}$. Based on the equation of the calibration curve, $\mathrm{Xi}$ ( $\mathrm{g} / \mathrm{L}$ ) values of concentration obtained experimentally were calculated.

From the calculation of performance parameters of the studied method, the following are noted:

- The linearity range of the method was between $0.5-2 \mathrm{~g} / \mathrm{mL}$, interval where the value of the correlation coefficient was 0.9906 ;

- If one takes into account smaller concentrations, the value of the correlation coefficient is 0.9903 ;

- Limit of detection was set for a concentration of $0.1088 \mathrm{~g} / \mathrm{mL}$;

- Limit of quantification was set for a concentration of $0.1295 \mathrm{~g} / \mathrm{mL}$;

- Accuracy is $99.36 \%$ and represents closeness between the real value and the determined value in the analysed sample;

- Standard deviation value is $0.00285 \mathrm{~g} / \mathrm{mL}$ (Macovescu et al., 2016).

\section{REFERENCES}

Albu, M.G. and Titorencu, I. (2011), "Biocompatibility study of collagen nerve conductors", Leather and Footwear Journal, 11(4), 329-340.

Albu, M.G., Deselnicu, V., Ioannidis, I., Deselnicu, D.C. and Chelaru, C. (2015), "Chemical functionalization and stabilization of type I collagen with organic tanning agents", Korean Journal of Chemical Engineering, 32(2), 354-361, DOI: 10.1007/s11814-014-0197-x.

Albu, M.G., Ficai, A. and Lungu, A. (2010), "Preparation and characterization of collagen matrices obtained at different freezing temperatures", Leather and Footwear Journal, 10(3), 39-50.

Albu, M.G., Ghica, M.V., Tang, K., Liu, J. and Coara, Gh. (2012a), "Rheological behavior of some collagen extracts", Leather and Footwear Journal, 12(3), 193-200.

Albu, M.G., Leca, M. and Trandafir, V. (2012b), "Rheological behaviour of some collagen creams", Leather and Footwear Journal, 12(4), 257-270.

Albu, M.G., Titorencu, I. and Chelaru, C. (2011), "The stability of some collagen hydrogels", Leather and Footwear Journal, 11(1), 11-20.

Albu, M.G., Trandafir, V., Leca, M. and Carsote, C. (2007), "Characterization of collagen-gentamicin systems used in controlled release of drugs", Leather and Footwear Journal, 7(4), 3-9.

De Ceuninck, F., Sabatini, M. and Pastoureau, P. (eds.) (2004), Methods in Molecular Medicine, Vol. 101: Cartilage and Osteoarthritis, Volume 2: Structure and In Vivo Analysis, () Humana Press Inc., Totowa, NJ.

Etherington, D.J. and Sims, T.J. (1981), "Detection and Estimation of Collagen", Journal of the Science of Food and Agriculture, 32, 539-546.

Macovescu, G., Chelaru, C., Kaya Albu, M.G. and Albu, L. (2016), "Determination of hydroxyproline in collagen biomaterials for medical use and validation of method", Leather and Footwear Journal, 16(2), 147-162.

Vranceanu, M.D., Saban, R., Albu, M.G. and Antoniac, I. (2012), "Preparation and characterization of collagen: amorphous calcium phosphate composites", Leather and Footwear Journal, 12(3), 215-222. 